\title{
The Image of Elderly People as Reflected in Israeli Children's Literature
}

\author{
Moshe Yitzhaki \\ yitzhm@biu.ac.il \\ Dept. of Information Studies, Bar-Ilan University, Ramat-Gan, Israel
}

\section{Mihal Lazar}

Dept. of Information Studies, Bar-Ilan University, Ramat-Gan, Israel

\begin{abstract}
Images of elderly people were checked in dozens of children's books published in Israel in Hebrew, designed usually for the consumption of the general, not orthodox, public. Generally speaking, images were positive, depicting the elderly people in various life circumstances.
\end{abstract}

Keywords: elderly people, children's literature, Israel

\section{Introduction}

As is well known, while children mature, they acquire, to a great extent, attitudes towards the world around them through exposure to various media, including books, and this remains with them as adults. Such attitudes also exist in the case of stereotypical and negative attitudes towards the elderly, identified as ageism. Some claim that as early as the age of three, children hold negative attitudes towards the elderly, and see old age in a negative light. In light of this, it is important to examine how elderly people are depicted in children's literature.

A common assumption is that children's books are an effective means of education and learning. Studies have shown that book reading may have positive effects, contributing to children's language control and writing abilities and pronunciation. The cumulative effect of content with distinct messages significantly affects children's perceptions. On the other hand, books and other media containing negative stereotypes of older people, their roles, behavior, and physical description, may be counterproductive to our common educational goals.

\section{Statement of the Research Question}

\section{General Background:}

The Divine command to respect old people is as long as the times of the Bible. The book of Leviticus says: "You shall rise up before the hoary head, and honor the face of the old man, and you shall fear your God" (ch. 19, v. 32). In the Jewish Talmud (i.e., the most authoritative book in Judaism after the Bible) there are many references to this command. The Jewish Sages interpreted the word 'Old Man' as "a man who acquired wisdom. The Talmud tells us about Rabbi Yohanan, one of the greatest Sages $\left(2^{\text {nd }}\right.$ Century AD), who rose up, even in his old age, before old people who passed by, Jews and non-Jews the like. He used to explain it to his disciples by saying: "These old people had gone into many adventures through their life, so they deserved getting due respect!" 
In view of this, it seemed quite interesting to examine how old people are portrayed in children's literature published in Israel in Hebrew. One should bear in mind that due to the sectorial division of the population in Israel religion-wise, there exist two entirely different genres of children's literature. One genre is designed for and is consumed by the general public, and the other one - by the orthodox and ultra-orthodox sectors. Thus, books of each sector deserve a separate study, assuming that those of the latter sectors, being more conservative and traditional, will contain positive images of elderly people.

The objective of the current study was to examine the image of elderly people in Israeli children's literature in Hebrew, written for the general public, found in school libraries, and to determine to what extent this image is negatively stereotyped.

\section{Literature Review}

Studies have done in the USA as well as in the UK, Italy, France, Greece, Poland, Finland (Sciplino, 2010), Syria (Szanto, 2012) and Israel (Bergson, 1987; Yaar-Wiesel, 2006). Generally speaking, they showed a mixed picture: while some books depict a positive image of elderly people, others reflect a negative one. In the few studies done in Israel, grandparents are usually described as pleasant, warm and loving people who live in peace with people around them.

\section{Methodology}

The children's books section in a school library in the Tel-Aviv metropolitan area was examined, searching for original children's books written in Hebrew by Israeli writers, dealing with elderly people in the family, i.e., grandparents. After locating such a book, it was analyzed according to the physical and mental image of the elderly, their gender, the role they play in the plot, the extent of their activity and its characteristics. The study examined these books on the basis of existing indices in the literature and additional indices developed in the process of reading these books.

\section{Findings and Discussion}

About $70 \%$ of the books found were published at the $21^{\text {st }}$ century, from the year 2000 on, so they present the perceptions of authors who have written over the last two decades.

Central Themes: Among the main themes is the elderly as caring and as active and amusing persons, like in Ruth Riesel-Moyal's 2002 "Granny's Garden," describing four elderly women who returned into a kindergarten for one day, playing with the facilities and toys of kindergarten children. Other themes are transfer of knowledge to a child, not family-related to him, and the personal or family history of the elderly person.

Most books describe the elderly as not in a couple-relationship, focusing on either one elderly woman or man, while only in a few cases does a living-together couple of elderly grandparents appear.

However, although most of the elderly appear as a single figure, it does not mean that they are isolated in the world, rather they are part of a continuous family system. It is manifested by the dominance of the theme describing the old person as a caring figure. It is similar to Sigalow and Fox's (2014) findings regarding books written for Jewish children in the US.

The majority of the books (82.5\%) tell about biological grandparents and their grandchildren, similar to the findings of Yaar-Wiesel (2006), while the rest deal with an elderly person and a child, if any, who is not related to him. About $60 \%$ of the books refer to only one grandchild, while $25 \%$ refer to 2 or 3 grandchildren, and 5 books refer to none. 
Regarding place of residence, most of the books $(67.5 \%)$ do not refer to any specific place of residence, while in others a reference is made to a distinct place, sometimes a fictitious one. No book, however, describes an elderly person who lives with his extended family.

As for whether the place of residence of the elderly person is a pleasant place, ambivalence can be noted: on the one hand there is no reference to it, and on the other hand it is described as a place.

In only $40 \%$ of the books, the elderly's home is being described as a pleasant place, where the child enjoys being. In three books, it is an unpleasant place, but more than half of the titles do not refer to this aspect at all.

This corroborates the findings of Ya'ar-Weisel (2006), who found concerning children's books written in Israel, that they portray elderly figures as pleasant, warm and loving characters.

Similar to the findings reported regarding children's books in the USA (Crawford \& Bhattacharya, 2014), here too, most of the books (82.5\%) do not refer at all to the elderly person's employment, and only 6 books mention a distinct occupation (a farmer, a scrap dealer, or a sculptor) or some non-realistic one. It may suggest that the employment issue of the elderly was not perceived by the writers as having any importance to the plot.

Contrary to the findings of Danowski \& Robinson (2012), in the vast majority of the books in our sample $(90 \%)$, the elderly figure was central to the plot, and only in four books $(10 \%)$ the elderly figure was marginal, indicating that authors attributed central weight to the elderly person, not only as a marginal figure accompanying the child.

As for the appearance of the elderly figure, 20 books (50\%) provide the reader with a stereotypical look: wearing eyeglasses, and having short gray-white hair. Concerning clothing, only few books describe women as wearing an apron and or long dress, while in 14 books they wear modern dress: pants or short dress.

In Danowski \& Robinson's (2012) review of the literature, older figures in children's books appear as individual and sickly figures. Our findings, however, suggest that in most of the books reviewed, old people are active part of a larger family or community, similar to the findings of Hollis-Sawyer and Cuevas (2013) where the elderly figures are described as active and contributing to the community, maintaining strong intergenerational ties.

\section{REFERENCES}

Baruch, M. (2008). Changes in the shaping of the image of grandparents in the family in contemporary children's literature. Literary and linguistic characteristics. or: about grand-grandparents and grandmas in the literature of contemporary children. Libra, 3-4, 2-6.

Bergson, Gershon (1987). Laugh between the folds; Grandparents and their grandchildren in the Hebrew children's literature. Tel-Aviv, Dvir. (in Hebrew)

Yaar-Wiesel, T. (2006). The old human figure in Israeli children's literature. Gerontology, 2, 35-54.

Crawford, P. A., \& Bhattacharya, S. (2014). Grand images: Exploring images of grandparents in picture books. Journal of Research in Childhood Education, 28(1), 128-144. 
Danowski, J., \& Robinson, T. (2012). The portrayal of older characters in popular children's picture books in the US: A content analysis from 2000 to 2010. Journal of Children and Media, 6(3), 333-350.

Hollis-Sawyer, L., \& Cuevas, L. (2013). Mirror, mirror on the wall: Ageist and sexist double jeopardy murals in children's picture books. Educational Gerontology, 39(12), 902-914.

Sciplino, C., Smith, P. K., Hurme, H., Rusek, M., \& Bäckvik, P. (2010). Representations of grandparents in children's books in Britain, Italy, Greece, Finland, and Poland. Journal of Intergenerational Relationships, 8(3), 298-316.

Sigalow, E., \& Fox, N. S. (2014). Perpetuating stereotypes: A study of gender, family, and religious life in Jewish children's books. Journal for the Scientific Study of Religion, 53(2), 416-431.

Szanto, E. (2012). Illustrating an Islamic childhood in Syria: Pious subjects and religious authority in twelve Shi'i children's books. Comparative Studies of South Asia, Africa and the Middle East, 32(2), 361-373.

\section{Biographical Note}

\section{Moshe Yitzhaki}

Born in Israel 1940. Undergraduate studies at Bar-Ilan University (economics and biblical studies) and Master degree in biblical studies there. MLS and PhD in Information and Library Studies at Rutgers University, New Jersey. From 1980 to 2009 full-time position at Bar-Ilan Department of Information Studies and director of the Jewish Studies Library. Senior lecturer (1988) and Associate Professor (2006). Research areas: scholarly communication, information storage and retrieval, bibliometrics/informetrics, digital readiness and development, children's literature, school media centers, censorship in libraries, biblical exegesis. 